\section{Lavandula angustifolia Growth and Physiology Is Affected by Substrate Type and Depth When Grown under Mediterranean Semi-intensive Green Roof Conditions}

\author{
George Kotsiris ${ }^{1}$, Panayiotis A. Nektarios, \\ and Angeliki T. Paraskevopoulou \\ Laboratory of Floriculture and Landscape Architecture, Department of Crop \\ Science, Agricultural University of Athens, 75, Iera Odos, 11855 Athens, Greece
}

Additional index words. adaptive green roofs, pumice, zeolite, compost, perlite, leaf stomatal resistance

\begin{abstract}
Green roofs have received increased interest as a result of their environmental, social, and economic benefits. The present study aims to evaluate suitable, lightweight substrates for the installation of semi-intensive-type green roofs and their effects on Lavandula angustifolia growth and physiological status under Mediterranean climatic conditions. The study was conducted in field containers $(1.2 \times 1.2 \mathrm{~m})$, and treatments included the use of two depths $(20 \mathrm{~cm}$ or $30 \mathrm{~cm})$ and three different substrates: 1$)$ pumice (Pum) mixed with peat $(P)$ and zeolite $(Z)$ in a volumetric proportion of 65:30:5 $\left(\right.$ Pum $\left.\left._{65}: \mathrm{P}_{30}: \mathrm{Z}_{5}\right) ; 2\right)$ pumice mixed with compost $(C)$ and zeolite in a volumetric proportion of 65:30:5 $\left(\mathrm{Pum}_{65}: \mathrm{C}_{30}: \mathrm{Z}_{5}\right)$; and 3) sandy loam soil (S) mixed with perlite (Per) and zeolite in a volumetric proportion of 30:65:5 $\left(\mathrm{S}_{30}: \mathrm{Per}_{65}: \mathrm{Z}_{5}\right)$. Each experimental plot was planted with four plants of $L$. angustifolia. The physical and chemical characteristics of the substrates and the in situ substrate moisture levels were determined. Plant growth was determined by the growth index and root dry weight, whereas the plant physiological status during the stressful summer period was determined by chlorophyll ${ }_{a+b}$ content and stomatal resistance. It was found that the bulk density of all of the substrates was less than $0.8 \mathrm{~g} \cdot \mathrm{cm}^{-3}$, whereas the water retention of substrate $S_{30}: P r_{65}: Z_{5}$ was greater than the other two substrates at all tensions. Substrate depth was the most influential factor; therefore, the deeper substrates $(30 \mathrm{~cm})$ provided higher growth indices and root dry weight, increased total chlorophyll content, and reduced leaf stomatal resistance compared with the shallower substrate depth of $20 \mathrm{~cm}$. Differences between substrate types were smaller compared with those of substrate depth. In spring, the growth index in substrate $P_{m_{65}}: C_{30}: Z_{5}$ was larger but not in the summer when the growth index of substrates $S_{30}: P r_{65}: Z_{5}$ and $P_{u_{65}}: P_{30}: Z_{5}$ exceeded that of the substrate amended with compost until the end of the study. In late summer, the plant total chlorophyll content decreased in all substrates, whereas substrate $P \mathrm{Pm}_{65}: \mathrm{C}_{30}: Z_{5}$ exhibited increased stomatal resistance compared with the other two substrates at the same period. It was concluded that $L$. angustifolia could be grown successfully in semi-intensive Mediterranean green roofs at a substrate depth of $20 \mathrm{~cm}$, but its growth and tolerance to the harsh summer conditions would improve at a substrate depth of $30 \mathrm{~cm}$.
\end{abstract}

Green roofs are multilayered constructions, which are classified as extensive, intensive, or semi-intensive. The classification among the

\footnotetext{
Received for publication 19 Sept. 2011. Accepted for publication 27 Dec. 2011.

This article is a portion of the $\mathrm{PhD}$ dissertation to be submitted by G. Kotsiris.

We thank L. Kabanis S.A. for providing the compost, the Athens Olympic Stadium "Spiros Louis" (OAKA) for donating the modules, and LAVA Mining \& Quarrying S.A. for partially supporting the research. The mention of a trademark, proprietary product, or vendor does not imply endorsement by the authors nor does it imply approval to the exclusion of other products that may also be suitable.

${ }^{1}$ To whom reprint requests should be addressed; e-mailgeokotsis@aua.gr.
}

three green roof types is based on both the substrate depth and type and concomitantly on the plant types capable to provide for sustainable growth on the roof and on the required maintenance level. Based on the guidelines set by Forschungsgesellschaft Landschaftsentwicklung Landschaftsbau e.V. (FLL, 2002), semi-intensive green roof systems have a depth of $12-100 \mathrm{~cm}$, an organic content of $6 \%$ to $12 \%$ by mass, and support vegetation of shrubs, coppices, grasses, and other groundcovers.

However, arguments have been raised against this formulaic classification of green roofs with regard to maintenance, which might change from one region to another according to the climate of each location (Fioretti et al., 2010). It seems that this type of argument might lead to an adaptive approach rather than a formalistic approach that is currently dominating the green roof industry.

In adaptive semi-intensive green roofing, the combination of limited water input with drought-tolerant plants would be the optimum solution for contemporary buildings in Mediterranean regions. In that sense, the adaptive approach would accommodate for a wider range of plant species increasing plant species diversity, contribute to the sustainability of the green roof systems, efficiently confront climatic extremes such as prolonged heat waves, and improve the aesthetic value of the green roof compared with the formulaic extensive green roofs comprised solely of Sedum species. If such an adaptive approach is adopted, the construction of semiintensive green roofs in the Mediterranean regions could increase. Such a potential increase is related to the desired improvement of the microclimatic conditions through the evapotranspiration and absorption of solar irradiation by plants (Skinner, 2006), which is also expected to ameliorate and mitigate the heat-island effect in contemporary cities if implemented on a large scale (Akbari et al., 2001; Getter and Rowe, 2006). In addition, microclimatic improvement is expected to occur more effectively from irrigated transpiring plants rather than from the minimal transpiration of CAM plants such as the Sedum species. Adaptive semi-intensive green roof systems are also related to the thermal performance of buildings that is expected to improve in proportion to the increase of the substrate depth (Wong et al., 2003). Kotsiris et al. (2010) and Niachou et al. (2001) found that extensive green roof types with a shallow depth have limited contribution to the thermal insulation of a building while Kotsiris et al. (2011) demonstrated that extensive green roofs with a shallow depth contribute to the cooling of a building in the summer but incur increased heating penalty during the winter.

In the urbanized Mediterranean region, the increased summer temperatures and annual water losses by evapotranspiration, compared with the input from precipitation, pose a significant obstacle for green roof construction. Therefore, research must be undertaken to exploit the potentials and overcome the limits of semi-intensive green roofs under semiarid conditions by fine-tuning for the most appropriate substrate type and depth, plant species, and amount of natural resources such as water, which need to be used (Williams et al., 2010).

Green roof substrates should be lightweight, chemically inert, physically stable, and they should retain adequate amounts of water and minerals for sufficient plant growth. In addition, they should be fast draining to avoid substrate saturation (Rowe et al., 2006). Therefore, the majority of green roof substrates tend to be dominated by mineralbased components (Beattie and Berghage, 2004) with an organic matter that varies according to the green roof type (FLL, 2008). In most cases, the organic matter of green roof substrates is composed of peat but composts 
offer an appropriate alternative in an effort to minimize the negative environmental impact of the horticultural use of peat (Gruda and Schnitzler, 2006; Lamanna et al., 1991; Ntoulas et al., 2011; Papafotiou et al., 2004).

Regarding the depth of the substrate, Dunnett et al. (2008) have demonstrated that the productivity, species richness, and diversity of 15 herbaceous, perennial grass and herb species were all greater at a substrate depth of $200 \mathrm{~mm}$ than at $100 \mathrm{~mm}$. Benvenuti and Bacci (2010) have also demonstrated that most of the 20 tested species that originated from dry habitats produced significantly greater vegetation cover and growth at a substrate depth of $150 \mathrm{~mm}$ as compared with $100 \mathrm{~mm}$.

In addition, it has been shown that irrigation has the capacity to negate the difficulties imposed on plant growth by shallow green roof substrates (Dunnett and Nolan, 2002; VanWoert et al., 2005). In moist climates, irrigation systems on extensive green roofs are optional, but they are recommended for the first 2 years to aid in the establishment and sustainable growth of plants during intense drought (Cantor, 2008). In the Mediterranean zone, the irrigation system is fundamental for semi-intensive-type green roofs, but the amount and frequency of water input depend on several factors such as the plant species and substrate type and depth. The combination of these factors should be optimized in an adaptive approach to achieve water conservation, taking into consideration that water is the most limiting natural resource in the Mediterranean zone (Fioretti et al., 2010; Gasith and Resh, 1999).

Considering the absence of local specifications and guidelines, the limited literature available on semi-intensive green roofs, and the desirability of expanding the construction of green roof systems in the Mediterranean or other semiarid regions, the challenge is to select appropriate substrates types and depths that would sustain semi-intensive green roof systems composed of adapted plant species. In such a case, it is preferable the substrates are comprised of lightweight materials with increased water-retention characteristics and are locally available in an effort to minimize the carbon footprint and support the local markets in a sustainable manner.

The present study aims to: 1) compose and evaluate suitable, lightweight substrates with a high water-retention capacity for semiintensive green roofs by using locally available materials; 2) investigate the potential substitution of horticultural peat by a locally available compost; 3) determine the impact of substrate type and depth on the growth of lavender plants; and 4) monitor the changes in physiological plant indicators during the summer stress period.

\section{Materials and Methods}

A field study was established at the Laboratory of Floriculture and Landscape Architecture at the Agricultural University of Athens (lat. $37^{\circ} 59^{\prime} \mathrm{N}$, long. $23^{\circ} 42^{\prime} 41^{\prime \prime} \mathrm{E}$ ), Athens, Greece. The study was initiated on 6 Oct. 2009 and was conducted until 29 Sept. 2010. The study comprised of 30 field experimental plots that were established in modules (GreenTech Inc., Richmond, VA) dimensioned $1.2 \times 1.2 \mathrm{~m}$ and filled with pea gravel as a drainage material to a depth of 12 $\mathrm{cm}$. Half of the plots were filled with a substrate to a depth of $20 \mathrm{~cm}$, whereas the other half to a depth of $30 \mathrm{~cm}$. The depth was adjusted with the use of plastic sleeves mounted on the sides of the modules. The lower portion of the module that was filled with the pea gravel was separated from the substrate by a non-woven geotextile to prevent particle migration from the substrate toward the drainage layer. The non-woven geotextile was a PET polyester (Drenotex AC3; Fraudenberg Politex S.a.s., Como, Italy) having a random fibrous structure, a weight of $150 \mathrm{~g} \cdot \mathrm{m}^{-2}$, a permeability index of 100 $\mathrm{mm} \cdot \mathrm{s}^{-1}$, and an aperture opening size of 180 $\mu \mathrm{m}$. The modules were filled with the following substrates: 1) Pumice mixed with Peat and clinoptilolite Zeolite in a volumetric proportion of 65:30:5 ( $\left.\mathrm{Pum}_{65}: \mathrm{P}_{30}: \mathrm{Z}_{5}\right) ; 2$ ) Pumice mixed with Compost and Zeolite in a volumetric proportion of $65: 30: 5\left(\mathrm{Pum}_{65}: \mathrm{C}_{30}: \mathrm{Z}_{5}\right)$; and 3 ) Sandy loam soil mixed with Perlite and Zeolite in a volumetric proportion of 30:65:5 $\left(\mathrm{S}_{30}: \mathrm{Per}_{65}: \mathrm{Z}_{5}\right)$. The pumice (LAVA Mining \& Quarrying S.A., Athens, Greece) had a particle-size distribution of $0.06-8 \mathrm{~mm}$, whereas the clinoptilolite zeolite (S\&B Industrial Minerals S.A., Athens, Greece) and perlite (Perloflor; ISOCON S.A., Athens, Greece) had a particle-size distribution of $0.8-2.5 \mathrm{~mm}$ and $1-5 \mathrm{~mm}$, respectively. The perlite, pumice, and zeolite were selected as locally available, coarse aggregate materials. Zeolite was used to improve plant growth by providing a slow release of nitrogen $(\mathrm{N})$ and potassium $(\mathrm{K})$ to the plants and to reduce $\mathrm{NH}_{4}^{+}$and $\mathrm{K}^{+}$leaching (Gül et al., 2005). The peat was a Lithuanian sphagnum peatmoss (Novobalt, Lithuania) with a $\mathrm{pH}$ of 3.75 . The compost was locally produced by L. Kabanis S.A., (Pikermi, Attika, Greece) from straw, sawdust, grass clippings, wood chips mixed with dairy cow, horse, and minimal amounts of chicken manure (for complete analysis, see Nektarios et al., 2011a) and was used as an alternative to peat in an effort to minimize the horticultural use of peat. Each material was selected based on their weight, water retention capacity, contribution to plant growth sustainability, and local availability. In addition, the substrate formulation using the selected materials aimed to comply with FLL specifications (FLL, 2008). Detailed characteristics of the substrates are given in Table 1.

Substrates chemical and physical characteristics. The substrate electrical conductivity (EC) and $\mathrm{pH}$ were determined in a $1: 2$ water dilution using a Consort $\mathrm{C}$ 835 Multichannel Analyzer (Consort NV, Belgium). The organic matter was determined by the loss on ignition at $450{ }^{\circ} \mathrm{C}$ overnight (ASTM D 2974-07a, 2000). After the removal of the organic matter by combustion, the mechanical analysis of the substrates was performed using the dry-sieving method according to ASTM D422-63 (2007) with the use of a vibrating sieve shaker (AS 200; Retsch $\mathrm{GmbH}$, Haan, Germany). Moisture retention curves as well as the porosity and both the dry and saturated bulk density were determined for each substrate according to Nektarios et al. (2011b and 2011a, respectively).

In situ substrate moisture content. The moisture content of the substrates was determined in situ with the use of a moisture meter (an $\mathrm{HH} 2$ unit in conjunction with a WET-2 sensor; Delta-T devices, Cambridge, U.K.). The specific equipment determined the volumetric water content with an accuracy of $\pm 3 \%$ from a soil volume of $65 \mathrm{~mm}$ deep $\times 45 \mathrm{~mm}$ wide. Substrate moisture measurements were performed from 18 May until 22 Sept. 2010 at biweekly intervals at $1200 \mathrm{HR}$. The sensor was placed $15 \mathrm{~cm}$ away from the dripper and at a depth of $10 \mathrm{~cm}$

Table 1. The chemical, physical, and nutrient analysis of the $\mathrm{Pum}_{65}: \mathrm{P}_{30}: \mathrm{Z}_{5}, \mathrm{Pum}_{65}: \mathrm{C}_{30}: \mathrm{Z}_{5}$, or $\mathrm{S}_{30}: \mathrm{Per}_{65}: \mathrm{Z}_{5}$ substrates.

\begin{tabular}{|c|c|c|c|c|}
\hline & $\operatorname{Pum}_{65}: \mathrm{P}_{30}: \mathrm{Z}_{5}$ & $\operatorname{Pum}_{65}: \mathrm{C}_{30}: \mathrm{Z}_{5}$ & $\mathrm{~S}_{30}: \operatorname{Per}_{65}: \mathrm{Z}_{5}$ & Method of analysis \\
\hline Organic matter $(\% \mathrm{w} / \mathrm{w})$ & 4.72 & 6.67 & 0.63 & Loss on ignition method (LOI) \\
\hline Total nitrogen $(\%)$ & 0.132 & 0.250 & 0.036 & Kjeldahl method \\
\hline Extractable phosphorus $\left(\mathrm{mg} \cdot \mathrm{kg}^{-1}\right)$ & 56.68 & 202.80 & 8.90 & Colorimetrically using a Hitachi U2001 spectrophotometer \\
\hline Exchangeable potassium $\left(\mathrm{mg} \cdot \mathrm{kg}^{-1}\right)$ & 945 & 2129 & 560 & Atomic absorption spectrophotometry (GBC 932A/A) \\
\hline Exchangeable magnesium $\left(\mathrm{mg} \cdot \mathrm{kg}^{-1}\right)$ & 249 & 605 & 99 & Atomic absorption spectrophotometry (GBC 932A/A) \\
\hline Exchangeable calcium $\left(\mathrm{mg} \cdot \mathrm{kg}^{-1}\right)$ & 2496 & 2793 & 2535 & Atomic absorption spectrophotometry (GBC 932A/A) \\
\hline Exchangeable sodium $\left(\mathrm{mg} \cdot \mathrm{kg}^{-1}\right)$ & 261 & 627 & 171 & Atomic absorption spectrophotometry (GBC 932A/A) \\
\hline $\mathrm{pH}(1: 2 \mathrm{v}: \mathrm{v}$ compost/water slurry) & 7.34 & 7.43 & 8.40 & Consort C 835 Multichannel Analyzer \\
\hline $\begin{array}{l}\text { Electrical conductivity }\left(\mu \mathrm{S} \cdot \mathrm{cm}^{-1}\right) \\
(1: 2 \mathrm{v}: \mathrm{v} \text { compost/water slurry })\end{array}$ & 567 & 1517 & 149 & Consort C 835 Multichannel Analyzer \\
\hline Saturated bulk density $\left(\mathrm{g} \cdot \mathrm{cm}^{-3}\right)$ & $1.14 \pm 0.03$ & $1.21 \pm 0.04$ & $1.22 \pm 0.04$ & Lysimeter, Nektarios et al., 2011b \\
\hline Dry bulk density $\left(\mathrm{g} \cdot \mathrm{cm}^{-3}\right)$ & $0.65 \pm 0.01$ & $0.78 \pm 0.02$ & $0.67 \pm 0.02$ & Lysimeter, Nektarios et al., 2011b \\
\hline Total porosity $(\%)$ & 44.8 & 43.0 & 53.0 & Lysimeter, Nektarios et al., 2011b \\
\hline
\end{tabular}

Pum = pumice; $\mathrm{P}=$ peat $; \mathrm{C}=$ compost; $\mathrm{S}=$ sandy loam soil; $\mathrm{Per}=$ perlite; $\mathrm{Z}=$ zeolite. 
over the geotextile for both substrate depths by using a metal cylinder that removed the substrate to the specific depth. The removed substrate was placed back to the hole after the soil moisture determination.

Experimental set-up. Lavandula angustifolia was selected as an appropriate plant species for a semi-intensive green roof as a result of its low water demands (Costello et al., 2000) and its abundance in the existing urban and suburban landscapes. Lavender plants are small bushes adapted to the Mediterranean ecosystems. The lavender plants had a height of $15 \mathrm{~cm}$ and were provided in $8-\mathrm{cm}$ peat plugs. Four plants were planted in each experimental plot on 4 Sept. 2010 in a $60 \times 60$-cm grid pattern.

The experimental plots were equipped with automated trickle irrigation. A single dripper that delivered $3 \mathrm{~L} \cdot \mathrm{h}^{-1}$ was placed at each lavender plant. In addition, a $200-\mathrm{L}$ fertigation tank was placed on the head of the irrigation system equipped with a proportional Bernoulli pump (MixRite type; Tefen Advanced Plastic Solutions, Israel) that provided a constant dilution of $0.8 \%$ of the batch solution. The irrigation program started on 3 Mar. 2010 and applied water three times per week with a duration of $30 \mathrm{~min}$ in each application. In such a way, each dripper delivered $1.5 \mathrm{~L}$ of water to each plant per irrigation that corresponded to $55 \%$ of lavender evapotranspiration demands averaged over July and August months. A permanent, but conservative, fertigation solution was applied through the irrigation system with 80 $\mathrm{mg} \cdot \mathrm{L}^{-1}$ of fertilizer, suitable for hydroponic cultivation, being delivered during each irrigation event. The fertilizer was of a 5-5-9 ratio $(4.5 \mathrm{~N}-2.2 \mathrm{P}-7.4 \mathrm{~K})$ with $2 \% \mathrm{NO}_{3}{ }^{-}-\mathrm{N}$, $0.5 \% \mathrm{NH}_{4}^{+}-\mathrm{N}$, and $2 \%$ organic $\mathrm{N}$ (Auxenol; Vioryl S.A., Afidnes, Greece) and included a total range of macro-, micro-, and trace elements, amino acids, and phytoextracts. In addition, a slow-release fertilizer comprised of $16-7-15(16 \mathrm{~N}-3.1 \mathrm{P}-12.5 \mathrm{~K})+1.2$ magnesium +3.6 sulfur with $2.1 \% \mathrm{NO}_{3}{ }^{-}-\mathrm{N}, 7.9 \%$ $\mathrm{NH}_{4}{ }^{+}-\mathrm{N}, 6 \% \mathrm{~N}^{\prime}$-(2-methylpropyliden)-bisurea (Floranid Permanent; Compo Hellas S.A., Maroussi, Greece) was applied once on 18 May 2010 at a rate of $35 \mathrm{~g}$ for each plant. Nitrogen application totaled to $0.45 \mathrm{~g} \cdot \mathrm{m}^{-2}$ and $22.4 \mathrm{~g} \cdot \mathrm{m}^{-2} \mathrm{~N}$ from fertigation and slowrelease fertilizer, respectively, for the whole duration of the study. The fertilization levels were established based on the findings reported by Biesiada et al. (2008) and Zollinger et al. (2006).

Meteorological data. The ambient maximum, minimum, and average temperature and precipitation (Fig. 1) were recorded by the Laboratory of General and Agricultural Meteorology at the Agricultural University of Athens.

Biometric measurements. The effect of the two substrate factors (type and depth) on the plant growth rate of the lavender plants was estimated by determination of their growth index. The growth index (GI) was determined by the following equation: $G I=\left(D_{1}+D_{2}+Z_{f}\right) / 3$, where $D_{1}=$ the largest foliage diameter, $D_{2}=$ the perpendicular

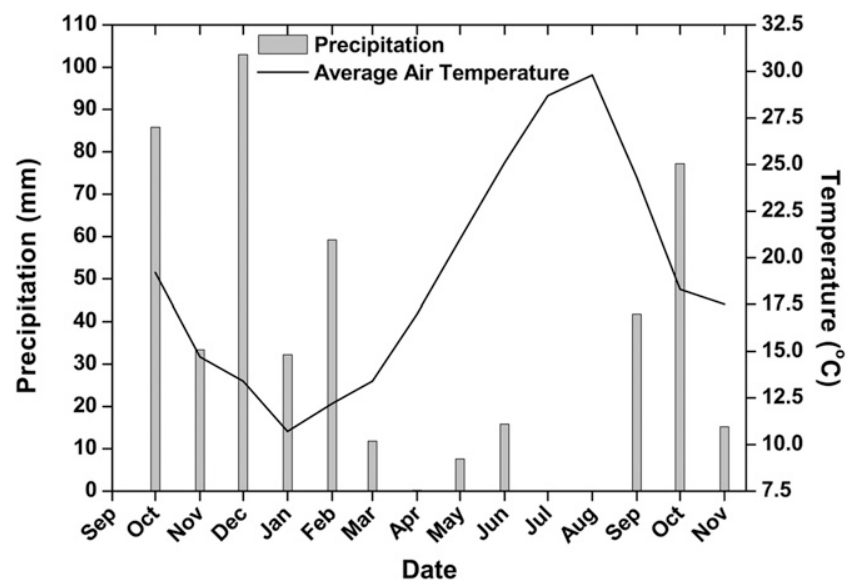

Fig. 1. The average air temperature and precipitation for the study period (2009-2010).

to the $D_{1}$ diameter of the foliage, and $Z_{f}=$ the height of the foliage measured from the junction of the stem with the lateral branches (Nektarios et al., 2011a; Ruter, 1996).

At the termination of the study (29 Sept. 2010), root dry weight was determined by destructively sampling three plants from each treatment. Plants were removed from the experimental plots, and the aerial parts were separated from the root systems. In addition, the substrate was removed with the use of a vacuum cleaner and was then screened to obtain all root parts. The roots were carefully separated from the substrate by rinsing with water and then were placed in a drying oven at $70{ }^{\circ} \mathrm{C}$ for $4 \mathrm{~d}$ to determine root dry weights.

Physiological measurements. A direct measurement of chlorophyll $\mathrm{a}$ and $\mathrm{b}$ content was implemented colorimetrically. More specifically, a randomly selected sample of $0.5 \mathrm{~g}$ fresh leaves, obtained from an initially larger sample, was homogenized and filtered through a $1001 \pm 125$ Whatman filter paper. The chlorophyll was extracted in the dark with $80 \%$ aqueous acetone in $50-\mathrm{mL}$ volumetric flasks. Measurements were performed on the supernatant with a spectrophotometer (Lamda 1A; Perkin Elmer, Waltham, MA) at 645 and $663 \mathrm{~nm}$. The chlorophyll a and b contents were determined according to Arnon's (1949) Eqs. [1] and [2] as follows:

$$
\begin{aligned}
C h l_{a}= & \left(12.7 \times D_{663}-2.69 \times D_{645}\right) \\
& \times \frac{V}{1000} \times w \\
C_{h}= & \left(22.9 \times D_{645}-4.68 \times D_{663}\right) \\
& \times \frac{V}{1000} \times w
\end{aligned}
$$

where $D_{663}, D_{645}=$ density values $\left(\mathrm{mg} \cdot \mathrm{L}^{-1}\right)$ at the respective wavelengths of 663 and 645 $\mathrm{nm}, V=$ volume of the extract, and $w=$ weight of the leaf samples. From Eqs. [1] and [2], the total chlorophyll content was derived as the sum:

$$
C h l_{a+b}=C h l_{a}+C h l_{b}
$$

Statistical analysis. Experimental units were arranged in a completely randomized plot design. The two factors $\left(3_{\text {substrates }} \times\right.$ $2_{\text {depths }}$ ) were replicated five times, resulting in a total number of 30 experimental plots. Analysis of variance for the biometric measurements (GI) was performed on the collected data using $\mathrm{JMP}^{\circledR}$ Version 8 statistical software (SAS Institute Inc., Cary, NC) following the repeated-measures model with the substrate treatment as the main plot, depth as the subplot, and time (sampling dates) as the sub-subplots. For all of the remaining measurements, the main research parameters were focused on the substrate type and depth effects within each separate sampling date. Therefore, multivariate analysis of variance was performed on the data collected with JMP $^{\circledR}$ Version 8 statistical software. The treatment means for all of the measurements were compared using the Fisher's protected least significant difference at a probability level of $P<0.05$ and the results were further confirmed with a paired $t$ test for the two substrate depths.

\section{Results and Discussion}

Physical and chemical characteristics of the substrates. All of the substrates were lightweight, their bulk density was less than $0.8 \mathrm{~g} \cdot \mathrm{cm}^{-3}$ (Table 1), and they retained adequate amounts of water at all tensions (Fig. 3). The $\mathrm{pH}$ of the substrates was within the specified limits, but for substrate $\mathrm{S}_{30}: \operatorname{Per}_{65}: Z_{5}$, it reached 8.4 (Table 1) close to the limit of 8.5 that has been established for green roofs (FLL, 2008). The $\mathrm{pH}$ increase was caused by the inclusion of soil in the mixture that had a $\mathrm{pH}$ of 8.61. The EC was within the specified range of FLL guidelines (FLL, 2008) for all substrates (Table 1). The EC was minimal for the $\operatorname{Pum}_{65}: \mathrm{P}_{30}: Z_{5}$ and $\mathrm{S}_{30}: \mathrm{Per}_{65}: Z_{5}$ substrates, but it was increased in substrate $\operatorname{Pum}_{65}: \mathrm{C}_{30}: \mathrm{Z}_{5}\left(1517 \mu \mathrm{S} \cdot \mathrm{cm}^{-1}\right)$ as a result of the increased $\mathrm{EC}$ of the compost (of $5700 \mu \mathrm{S} \cdot \mathrm{cm}^{-1}$ ).

All substrates complied with the FLL guidelines with regard to the maximum allowable percentage of silt and clay, total porosity, nutrient level (Table 1), and particle size distribution (Fig. 2). As expected, the particle size distribution was almost identical 
for the $\mathrm{Pum}_{65}: \mathrm{P}_{30}: \mathrm{Z}_{5}$ and $\mathrm{Pum}_{65}: \mathrm{C}_{30}: \mathrm{Z}_{5}$ substrates, whereas the $\mathrm{S}_{30}: \operatorname{Per}_{65}: Z_{5}$ substrate had a significantly finer particle distribution compared with the other two substrates as a result of the soil inclusion. The organic matter content of the $\operatorname{Pum}_{65}: \mathrm{C}_{30}: Z_{5}$ and $\operatorname{Pum}_{65}: \mathrm{P}_{30}: \mathrm{Z}_{5}$ substrates was $6.67 \%$ and $4.72 \% \mathrm{w} / \mathrm{w}$, respectively, and complied with the specified range (less than $12 \%$ by weight for substrates with a bulk density less than $0.8 \mathrm{~g} \cdot \mathrm{cm}^{-3}$ ), whereas the $S_{30}: P e_{65}: Z_{5}$ substrate had a minimal organic matter content of $0.63 \% \mathrm{w} / \mathrm{w}$ (Table 1$)$.

A difference in the water-retention capacity was noted among the three substrates. The $\mathrm{S}_{30}: \mathrm{Per}_{65}: Z_{5}$ substrate retained larger quantities of water compared with the $\mathrm{Pum}_{65}: \mathrm{C}_{30}: \mathrm{Z}_{5}$ and $\mathrm{Pum}_{65}: \mathrm{P}_{30}: \mathrm{Z}_{5}$ at all tensions (Fig. 3). Differences in water retention were also observed between the $\operatorname{Pum}_{65}: \mathrm{P}_{30}: \mathrm{Z}_{5}$ and $\operatorname{Pum}_{65}: \mathrm{C}_{30}: Z_{5}$ substrates; the peat-supplemented substrate provided a lower water retention at all tensions as compared with the $\operatorname{Pum}_{65}: \mathrm{C}_{30}: \mathrm{Z}_{5}$ substrate.

In situ substrate moisture measurements. The in situ measurements for the volumetric moisture content $(\%, v / v)$ of the substrates quickly reduced from mid-May until June 2010 and remained at low levels until Sept. 2010 as a result of the complete lack of rainfalls, the increasing summer evapotranspiration, and the deficit replenishment by irrigation (Fig. 4). The substrate type and depth did not significantly affect the moisture content except on two dates in early June when the $\mathrm{S}_{30}: \mathrm{Per}_{65}: \mathrm{Z}_{5}$ substrate had a greater moisture content compared with the other two substrates. The moisture level was very low ( $5 \%$ to $7 \% \mathrm{v} / \mathrm{v})$ in July and August but similar between all treatments. These results were expected because in adequate moisture conditions, the perched water table over the geotextile is regulated by the water potential curve of each substrate and therefore it was higher in the $\mathrm{S}_{30}: \mathrm{Per}_{65}: \mathrm{Z}_{5}$ compared with the other two substrates. However, at very low substrate moisture levels, the height of the perched water table is reduced to similar levels and therefore differences between the substrates' moisture were negated. Differences between the two substrate depths were not significant except from one measurement in June 2010, in which the deeper substrates $(30 \mathrm{~cm})$ had increased moisture compared with the 20-cm deep substrates.

Biometric measurements. Plant growth was initiated in early Mar. 2010 and continued through the summer and fall periods until the end of the study in early October (Fig. 5). The plants grown in the $\mathrm{Pum}_{65}: \mathrm{C}_{30}: \mathrm{Z}_{5}$ substrate had a larger GI before the application of the fertilization (Fig. 5). These differences were attributed to the higher nutritional status of the compost-supplemented substrate $\left(\right.$ Pum $\left._{65}: \mathrm{C}_{30}: \mathrm{Z}_{5}\right)$ as compared with the peatand soil-amended substrates (Table 1). However, after the application of the slow-release fertilizer (18 May 2010), the GI of the two substrates $\left(\mathrm{S}_{30}: \operatorname{Per}_{65}: \mathrm{Z}_{5}\right.$ and $\left.\mathrm{Pum}_{65}: \mathrm{P}_{30}: \mathrm{Z}_{5}\right)$ exhibited a sigmoid growth in contrast to the linear growth of the $\mathrm{Pum}_{65}: \mathrm{C}_{30}: \mathrm{Z}_{5}$ substrate.

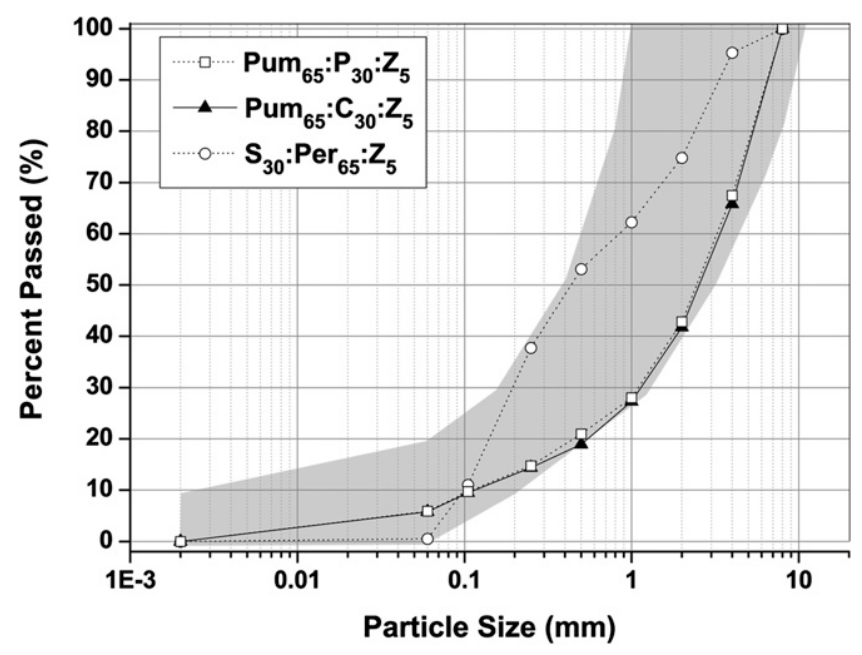

Fig. 2. The particle size distribution of substrates $\operatorname{Pum}_{65}: \mathrm{P}_{30}: Z_{5}, \operatorname{Pum}_{65}: \mathrm{C}_{30}: \mathrm{Z}_{5}$, and $\mathrm{S}_{30}: \operatorname{Per}_{65}: \mathrm{Z}_{5}(\mathrm{Pum}=$ pumice; $\mathrm{P}=$ peat $\mathrm{C}=$ compost; $\mathrm{S}=$ sandy loam soil; $\mathrm{Per}=$ perlite; $\mathrm{Z}=$ zeolite). The gray area represents the appropriate substrate selection range for intensive green roofs following the FLL guidelines (FLL, 2008).

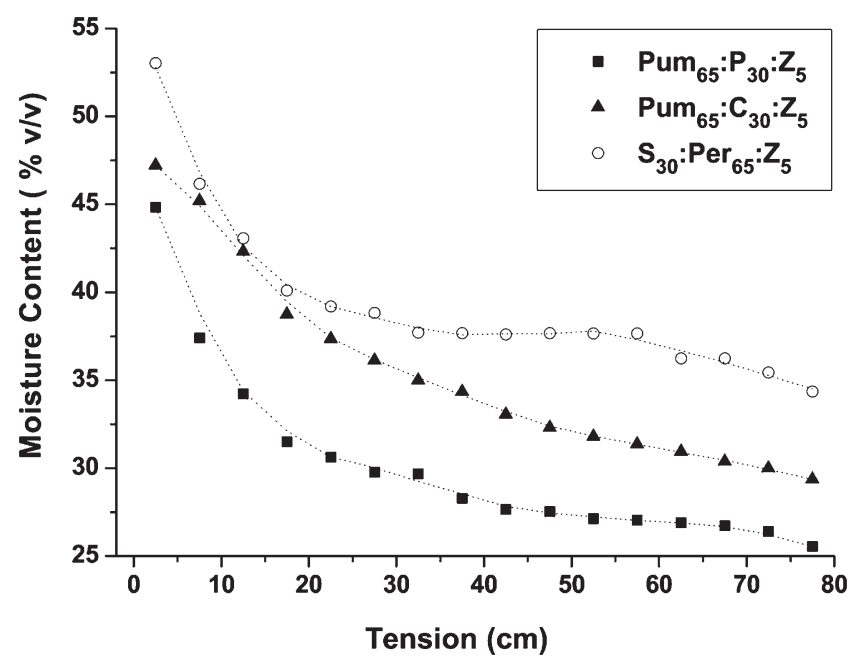

Fig. 3. Water potential curves for substrates $\operatorname{Pum}_{65}: \mathrm{P}_{30}: \mathrm{Z}_{5}, \mathrm{Pum}_{65}: \mathrm{C}_{30}: \mathrm{Z}_{5}$, and $\mathrm{S}_{30}: \operatorname{Per}_{65}: \mathrm{Z}_{5}(\mathrm{Pum}=$ pumice; $\mathrm{P}=$ peat; $\mathrm{C}=$ compost $\mathrm{S}=$ sandy loam soil; $\mathrm{Per}=$ perlite; $\mathrm{Z}=$ zeolite). Values are the means of three replications.

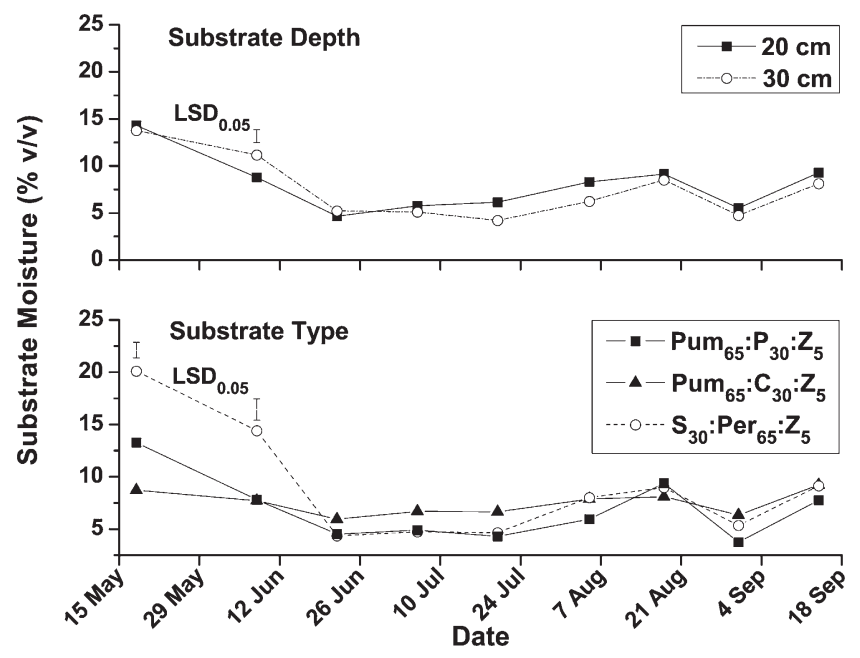

Fig. 4. Substrate moisture content fluctuation, as affected by substrate depth $(20$ or $30 \mathrm{~cm})$ and type $\left(\operatorname{Pum}_{65}: \mathrm{P}_{30}: \mathrm{Z}_{5}, \mathrm{Pum}_{65}: \mathrm{C}_{30}: \mathrm{Z}_{5}\right.$, or $\mathrm{S}_{30}: \mathrm{Per}_{65}: \mathrm{Z}_{5}$, in which Pum = pumice; $\mathrm{P}=$ peat; $\mathrm{C}=$ compost; $\mathrm{S}=$ sandy loam soil; $P e r=$ perlite; $Z=$ zeolite). Values are the mean of five replicates. Bars represent the Fisher's least significance difference (LSD) at $P<0.05$. 
This different growth pattern resulted in larger GI for both substrates $\mathrm{S}_{30}: \operatorname{Per}_{65}: \mathrm{Z}_{5}$ and $\operatorname{Pum}_{65}: \mathrm{P}_{30}: Z_{5}$ from 20 July until the end of the study. It is speculated that the increased early spring growth of the compost-amended substrate made it more vulnerable to the summer stressful conditions. These findings are in accordance with the findings of several researchers. Nagase and Dunnett (2011) found that plants growing in compost-rich substrates were more prone to water stress conditions. Similarly Rowe et al. (2006) reported that increased nutrient availability resulted in plants with increased foliage, prone to increased transpiration, and thus with reduced drought stress tolerance.

In comparison with the $20-\mathrm{cm}$ depth substrates, the deeper substrates (30-cm depth) increased the GI from early May until the end of the study (29 Sept. 2010). This was the result of the increased root dry weight of the plants growing in the deeper substrates (Table 2). Zollinger et al. (2006) referred that
L. angustifolia and other Mediterranean brushwood herbs and shrubs have a root system that combines shallow and deep roots simultaneously, indicating an environmental adaptation that improves their capacity to exploit the soil moisture from various depths. Although in the current study root growth by depth was not investigated, it is speculated that the deeper substrates permitted the development of a deeper root system, which led to the better growth of plants. Similar beneficial effects on plant growth and survival have been documented by several researchers in extensive green roof types (Durhman et al., 2007; Getter and Rowe, 2009; VanWoert et al., 2005), which have been attributed to the amelioration of the substrate temperature fluctuation and extremes (Boivin et al., 2001), to the increased volume of the substrate for potential root expansion as well as to the increased moisture content of the substrate (Getter and Rowe, 2009; VanWoert et al., 2005).

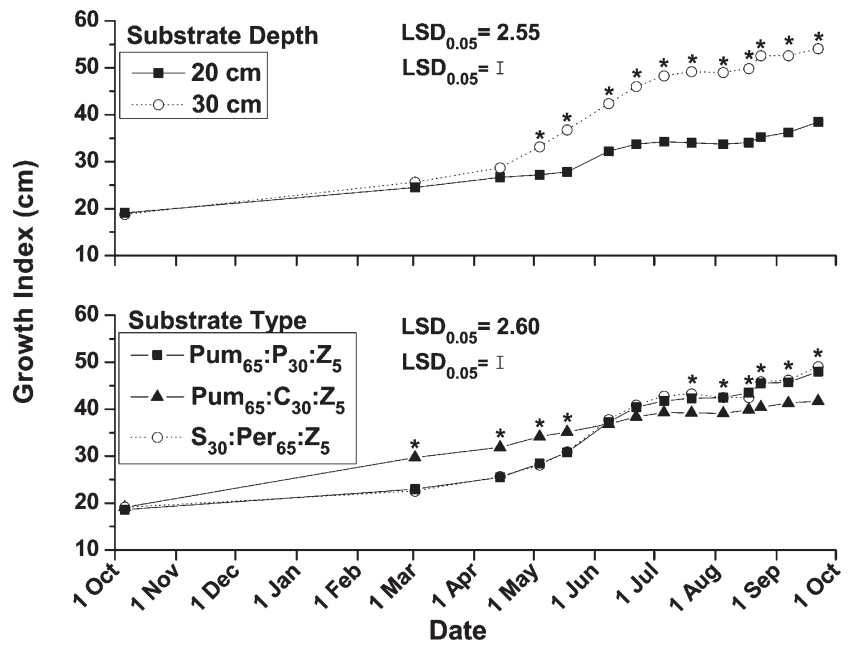

Fig. 5. The growth index for Lavandula angustifolia as affected by substrate depth $(30 \mathrm{~cm}$ or $20 \mathrm{~cm})$ and substrate type $\left(\operatorname{Pum}_{65}: \mathrm{P}_{30}: \mathrm{Z}_{5}, \mathrm{Pum}_{65}: \mathrm{C}_{30}: \mathrm{Z}_{5}\right.$, or $\mathrm{S}_{30}: \mathrm{Per}_{65}: \mathrm{Z}_{5}$, in which $\mathrm{Pum}=$ pumice; $\mathrm{P}=$ peat; $\mathrm{C}=$ compost; $\mathrm{S}=$ sandy loam soil; $\mathrm{Per}=$ perlite; $\mathrm{Z}=$ zeolite). Values are the mean of five replicates. Bars represent the Fisher's least significance difference (LSD) at $P<0.05$ following the repeated-measures model. The asterisk $(*)$ represents significant differences in-between treatment means on a single sampling date.

Table 2. Analysis of variance table and table of means for Lavandula angustifolia root dry weight as affected by substrate depth $(20$ or $30 \mathrm{~cm})$ and substrate type $\left(\operatorname{Pum}_{65}: \mathrm{P}_{30}: \mathrm{Z}_{5}, \operatorname{Pum}_{65}: \mathrm{C}_{30}: \mathrm{Z}_{5}\right.$, or $\mathrm{S}_{30}: \mathrm{Per}_{65}: \mathrm{Z}_{5}$ in which Pum = pumice; $\mathrm{P}=$ peat $\mathrm{C}=$ compost; $\mathrm{S}=$ sandy loam soil; $\mathrm{Per}=$ perlite; $\mathrm{Z}=$ zeolite).

\begin{tabular}{lcrccc}
\hline Source & Sum of squares & df & Mean square & F-Ratio & $P$ \\
\hline Substrate depth (SD) & 1336.68 & 1 & 1336.68 & 7.04 & 0.0162 \\
Substrate type (ST) & 61.90 & 2 & 30.95 & 0.16 & 0.8509 \\
Interaction (SD $\times$ ST) & 784.50 & 2 & 392.25 & 2.06 & 0.1558 \\
Residual & 3419.23 & 18 & 189.96 & & \\
Total & 5602.33 & 23 & & &
\end{tabular}

Table of means

\begin{tabular}{lclc}
\hline Substrate depth $(\mathrm{SD})$ & Root dry wt $(\mathrm{g})$ & \multicolumn{1}{c}{ Substrate type $(\mathrm{ST})$} & Root dry wt $(\mathrm{g})$ \\
\hline $20 \mathrm{~cm}$ & 51.3 & $\mathrm{Pum}_{65}: \mathrm{P}_{30}: \mathrm{Z}_{5}$ & 57.9 \\
$30 \mathrm{~cm}$ & 66.2 & $\mathrm{Pum}_{65}: \mathrm{C}_{30}: \mathrm{Z}_{5}$ & 61.0 \\
$t_{\text {experimental }}$ & 2.62 & $\mathrm{~S}_{30}: \mathrm{Per}_{65}: \mathrm{Z}_{5}$ & 57.4 \\
$t_{\text {critical }}$ & 2.08 & Least significant difference & 16.89 \\
Significance & $*$ & Significance & NS \\
\hline
\end{tabular}

*Significant at $P<0.05$

NS $=$ nonsignificant at $P<0.05$.
Physiological measurements. The total chlorophyll content gradually reduced from May until the end of the stressful summer period that coincided with the first September rainfall events (Figs. 1 and 6). Within 2 weeks after the autumn rainfall events (11 Sept. 2010), the total chlorophyll content quickly recovered to levels that were similar to those of May.

Chlorophyll is a known indicator of the physiological status of the plants, which reduces when plants are subjected to various stresses (Dubey, 2005). The plants that grew in deeper substrates had increased total chlorophyll content for the whole duration of the study except from a single measurement in early June. This confirmed the fact that the lavender plants growing in the deeper profiles had more aerial and root growth, which was feasible as a result of the better physiological plant status. Concerning the different substrate types, substrate $\mathrm{S}_{30}: \operatorname{Per}_{65}: Z_{5}$ had the highest chlorophyll content from June to mid-July, substrate $\mathrm{Pum}_{65}: \mathrm{P}_{30}: \mathrm{Z}_{5}$ moderate and substrate $\mathrm{Pum}_{65}: \mathrm{C}_{30}: \mathrm{Z}_{5}$ the least. In August, the total chlorophyll $\mathrm{a}_{\mathrm{a}}$ content dropped in all substrates after the augmenting summer stresses. Durhman et al. (2006) have found similar reduction of chlorophyll fluorescence in non-CAM plants when subjected to different dry cycles. The researchers found that non-CAM plants needed irrigation every other day to sustain adequate photosynthetic activity. Two weeks after the September rainfalls, the total chlorophyll content increased in all substrates and on the 1 Oct. 2010, substrate $\mathrm{S}_{30}: \mathrm{Per}_{65}: \mathrm{Z}_{5}$ had a larger total chlorophyll content compared with substrate Pum $_{65}: C_{30}: Z_{5}$ indicating that the factors that provided for the growth differences between the substrate types before the stressful summer period still existed (Fig. 6). Based on the findings of Flexas et al. (2004), who demonstrated that the speed of the recovery of photosynthetic activity depends on the severity of the imposed water deprivation, lavender plants were severely stressed because they recovered 2 weeks after the first fall rainfall event. However, the recovery of total chlorophyll content within 2 weeks indicated that the summer stresses did not affect the lavender plants' capacity for photosynthesis (Nogues and Alegre, 2002).

The increased summer stress that the plants in the shallow substrates $(20 \mathrm{~cm})$ were subjected to was further substantiated based on their increased stomatal resistance compared with the plants in deeper substrates (30 $\mathrm{cm}$ ) (Fig. 7). Differences were negated after September rainfall events (Figs. 1 and 7). Regarding substrate types, substrate $\mathrm{Pum}_{65}: \mathrm{C}_{30}: \mathrm{Z}_{5}$ exhibited increased stomatal resistance compared with the other two substrates further substantiating that this particular substrate imposed more stress to the plants during the summer (Fig. 7). The increased stomatal resistance of substrate $\operatorname{Pum}_{65}: \mathrm{C}_{30}: \mathrm{Z}_{5}$ was in accordance with the reduced chlorophyll content (Fig. 6) as a result of the reduced photosynthetic activity. As Dubey (2005) refers, water stress reduces plant growth and affects photosynthesis by reducing leaf 


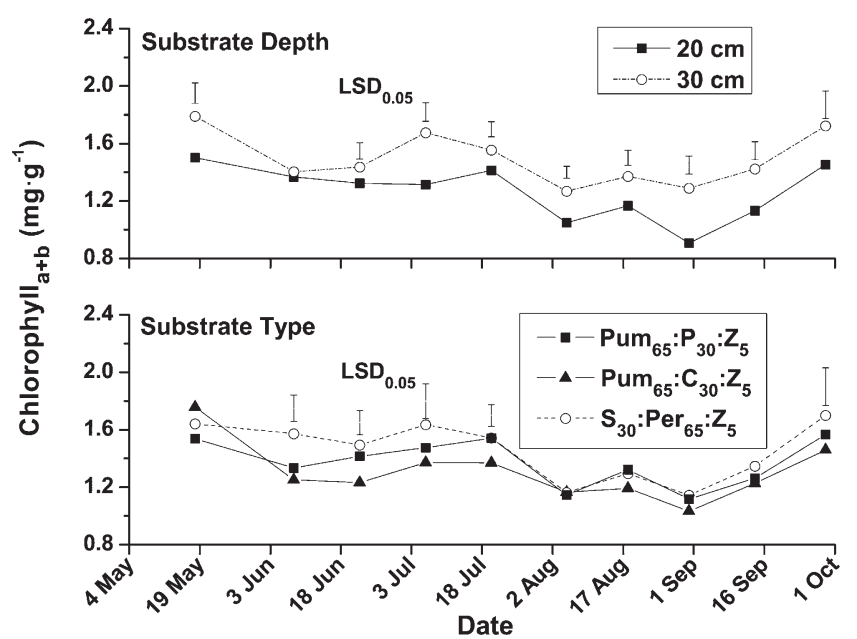

Fig. 6. The chlorophyll $\mathrm{a}_{\mathrm{a}+\mathrm{b}}$ content of Lavandula angustifolia as affected by substrate depth $(30 \mathrm{~cm}$ or 20 $\mathrm{cm})$ and type $\left(\operatorname{Pum}_{65}: \mathrm{P}_{30}: Z_{5}, \operatorname{Pum}_{65}: \mathrm{C}_{30}: Z_{5}\right.$, or $\mathrm{S}_{30}: \operatorname{Per}_{65}: \mathrm{Z}_{5}$, in which $\mathrm{Pum}=$ pumice; $\mathrm{P}=$ peat; $\mathrm{C}=$ compost; $\mathrm{S}=$ sandy loam soil; $\mathrm{Per}=$ perlite; $\mathrm{Z}=$ zeolite). Values are the mean of five replicates. Bars represent the Fisher's least significance difference (LSD) at $P<0.05$.

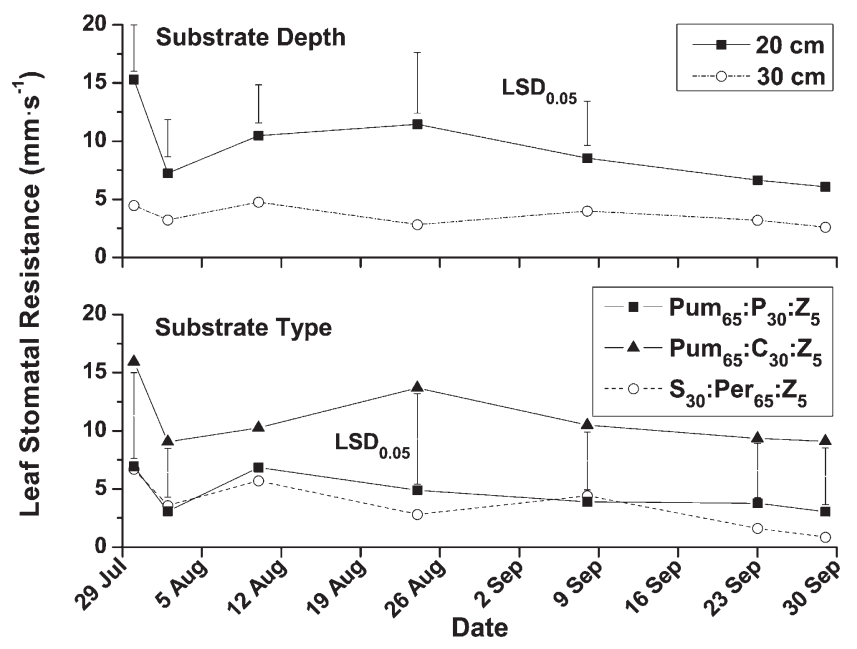

Fig. 7. The leaf stomatal resistance values of Lavandula angustifolia as affected by substrate depth $(20 \mathrm{~cm}$ or $30 \mathrm{~cm})$ and type $\left(\mathrm{Pum}_{65}: \mathrm{P}_{30}: \mathrm{Z}_{5}, \mathrm{Pum}_{65}: \mathrm{C}_{30}: \mathrm{Z}_{5}\right.$, or $\mathrm{S}_{30}: \mathrm{Per}_{65}: \mathrm{Z}_{5}$, in which $\mathrm{Pum}=$ pumice; $\mathrm{P}=$ peat; $\mathrm{C}$ $=$ compost $\mathrm{S}=$ sandy loam soil; $\mathrm{Per}=$ perlite; $\mathrm{Z}=$ zeolite). Values are the mean of five replicates. Bars represent the Fisher's least significance difference (LSD) at $P<0.05$.

area, enhancing stomatal closure, decreasing water status in the leaf tissues, reducing the rate of $\mathrm{CO}_{2}$ assimilation, causing ultrastructural changes in chloroplasts, affecting electron transport and $\mathrm{CO}_{2}$ assimilation reactions impairing ATP synthesis and RUBP generation. Nogués and Baker (2000) have also found that lavender leaves exhibit increased stomatal resistance during drought treatments under no supplementary irrigation during summer.

\section{Conclusions}

The use of locally available materials for the development of semi-intensive green roof substrates was proved to be successful because they complied with the FLL guidelines (FLL, 2008) and supported adequate lavender growth during all seasons as well as during the harsh Mediterranean summer conditions. Substrate depth was the most
It was concluded that semi-intensive green roofing, based on locally available lightweight substrates with a high water retention capacity in combination with drought-tolerant plants, could be an adaptive approach that will serve as a sustainable option for contemporary buildings and cities in Mediterranean regions.

\section{Literature Cited}

Akbari, H., M. Pomerrantz, and H. Taha. 2001. Cool surfaces and shade trees to reduce energy use and improve air quality in urban areas. Sol. Energy 70:295-310.

Arnon, D.I. 1949. Copper enzymes in isolated chloroplasts. Polyphenoloxidase in Beta vulgaris. Plant Physiol. 24:1-15.

ASTM D 2974-07a. 2007. Standard test methods for moisture, ash, and organic matter of peat and other organic soils. American Society for Testing and Materials, West Conshohocken, PA.

ASTM D 422-63. 2007. Standard test method for particle-size analysis of soils. American Society for Testing and Materials, West Conshohocken, PA.

Beattie, D.J. and R.D. Berghage. 2004. Green roof media characteristics: The basic, p. 411-416. In: Proc. of 2nd North American Green Roof Conference: Greening Rooftops for Sustainable Communities Conference, Portland, OR, 2-4 June 2004. The Cardinal Group, Toronto, Canada.

Benvenuti, S. and D. Bacci. 2010. Initial agronomic performances of Mediterranean xerophytes in simulated dry green roofs. Urban Ecosyst. 13:349-363.

Biesiada, A., A. Sokol-Letowska, and A. Kucharska. 2008. The effect of nitrogen fertilization on yielding and antioxidant activity of lavender (Lavandula angustifolia Mill.). Acta Scientiarum Polonorum 7:33-40.

Boivin, M., M. Lamy, A. Gosselin, and B. Dansereau. 2001. Effect of artificial substrate depth on freezing injury of six herbaceous perennials grown in a green roof system. HortTechnology 11:409-412.

Cantor, S. 2008. Green roofs in sustainable landscape design. 1st Ed. W.W. Norton \& Co., New York, NY.

Costello, L.R., K.S. Jones, N.P. Matheny, and J.R. Clark. 2000. Estimating the irrigation water needs of landscape plantings in California: The landscape coefficient method. Water Use Classification of Landscape Species (WUCOLS III). University of California Cooperative Extension.

Dubey, S.R. 2005. Photosynthesis in plants, under stressful conditions, p. 859-876. In: Ressarkli, M. (ed.). Handbook of photosynthesis. 2nd Ed. Taylor \& Francis, London, U.K.

Dunnett, N., A. Nagase, and A. Hallam. 2008. The dynamics of planted and colonising species on a green roof over six growing seasons 20012006: Influence of substrate depth. Urban Ecosyst. 11:373-384

Dunnett, N. and A. Nolan. 2002. The effect of substrate depth and supplementary watering on the growth of nine herbaceous perennials in a semi-extensive green roof. Acta Hort. 643:305-309.

Durhman, A.K., D.B. Rowe, and C.L. Rugh. 2006 Effect of water regimen on chlorophyll fluorescence and growth of selected green roof plant taxa. HortScience 41:1623-1628.

Durhman, A.K., D.B. Rowe, and C.L. Rugh. 2007 Effect of substrate depth on initial growth, coverage, and survival of 25 succulent green roof plant taxa. HortScience 42:588-595. 
Fioretti, R., A. Palla, L.G. Lanza, and P. Principi. 2010. Green roof energy and water related performance in the Mediterranean climate. Build. Environ. 45:1890-1904.

Flexas, J., J. Bota, J. Cifre, J.M. Escalona, J. Galmés, J. Gulías, K. Lefi, S.F.M. Cañellas, M.T. Moreno, M.R. Carbó, D. Riera, B. Sampol, and H. Medrano. 2004. Understanding down-regulation of photosynthesis under water stress: Future prospects and searching for physiological tools for irrigation management. Ann. Appl. Biol. 144:273-283.

Forschungsgesellschaft Landschaftsentwicklung Landschaftsbau e.V. (FLL). 2002 and 2008. Richtlinien für die Planung, Ausführung und Pflege von Dachbegrünungen. Richtlinien für Dachbegrünungen (Guideline for the planning, execution and upkeep of green-roof sites). Selbstverlag, Troisdorf.

Gasith, A. and V.H. Resh. 1999. Streams in Mediterranean climate regions: Abiotic influences and biotic responses to predictable seasonal events. Annu. Rev. Ecol. Syst. 30:51-81.

Getter, L.K. and D.B. Rowe. 2006. The role of extensive green roofs in sustainable development. HortScience 41:1276-1285.

Getter, L.K. and D.B. Rowe. 2009. Substrate depth influences Sedum plant community on a green roof. HortScience 44:401-407.

Gruda, N. and W.H. Schnitzler. 2006. Wood fiber substrates as a peat alternative for vegetable productions. Europ. J. Wood and Wood Products 64:347-350.

Gül, A., E. Deniz, and O. Ali Riza. 2005. Comparison of the use of zeolite and perlite as substrate for crisp-head lettuce. Sci. Hort. 106:464-471.

Kotsiris, G., A. Androutsopoulos, and P.A. Nektarios. 2010. Thermal performance of semi-intensive type, planted roofs in Greece. 3rd International Conference, PALENC2010, Rhodes, Greece. Conference Proc., USB Flash Drive. ISBN: 978-960-6746-08-6.

Kotsiris, G., A. Androutsopoulos, E. Polychroni, and P.A. Nektarios. 2011. Dynamic U-value estimation and energy simulation for green roofs. Energy and Build. 45:240-249.

Lamanna, D., M. Castelnuovo, and G. D’Angelo. 1991. Compost-based media as alternative to peat on ten pot ornamentals. Acta Hort. 294: 125-130.

Nagase, A. and N. Dunnett. 2011. The relationship between percentage of organic matter in substrate and plant growth in extensive green roofs. Landsc. Urban Plan. 103:230-236.

Nektarios, P.A., I. Amountzias, I. Kokkinou, and N. Ntoulas. 2011a. Green roof substrate type and depth affects the growth of the native species Dianthus fruticosus under reduced irrigation regimens. HortScience 46:12081216.

Nektarios, P.A., S. Kastritsis, N. Ntoulas, and P. Tsiotsiopoulou. 2011b. Substrate amendment effects on potted plant production and dry weight partition of Lantana camara. HortScience 46:864-869.

Niachou, A., K. Papakonstantinou, M. Santamouris, G. Tsangrassoulis, and G. Mihalakakou. 2001. Analysis of the green roof thermal properties and investigation of its energy performance. Energy Build. 33:719-729.

Nogues, S. and L. Alegre. 2002. An increase in water deficit has no impact on the photosynthetic capacity of field-grown Mediterranean plants. Funct. Plant Biol. 29:621-630.

Nogués, S. and N.R. Baker. 2000. Effects of drought on photosynthesis in Mediterranean plants grown under enhanced UV-B radiation. J. Expt. Bot. 51:1309-1317.

Ntoulas, N., P.A. Nektarios, and G. Gogoula. 2011. Evaluation of olive mill waste compost as a soil amendment for Cynodon dactylon turf establishment, growth and anchorage. HortScience 46:937-945.

Papafotiou, M., M. Phsyhalou, G. Kargas, I. Chatzipavlidis, and J. Chronopoulos. 2004. Olive-mill wastes compost as growing medium component for the production of poinsettia. Sci. Hort. 102: 167-175.

Rowe, D.B., M.A. Monterusso, and C.L. Rugh. 2006. Assessment of heat-expanded slate and fertility requirements in green roof substrates. HortTechnology 16:471-477.

Ruter, J.M. 1996. Paclobutrazol application method influences growth and flowering of "new gold" lantana. HortTechnology 6:19-20.

Skinner, C.J. 2006. Urban density, meteorology and rooftops. Urban Policy Res. 24:355-367.

VanWoert, N.D., D.B. Rowe, J.A. Andresen, C.L. Rugh, and L. Xiao. 2005. Watering regime and green roof substrate design affect Sedum plant growth. HortScience 40:659-664.

Williams, S.G.N., P.J. Rayner, and J.K. Raynor 2010. Green roofs for a wide brown land: Opportunities and barriers for rooftop greening in Australia. Urban For. Urban Green. 9:245-251.

Wong, N.H., D.K.W. Cheong, H. Yan, J. Soh, C.L. Ong, and A. Sia. 2003. Investigation of thermal benefits of rooftop garden in the tropical environment. Energy Build. 35:353-364.

Zollinger, N., R. Kjelgren, T. Cerny-Koenig, K. Kopp, and R. Koenig. 2006. Drought responses of six ornamental herbaceous perennials. Sci. Hort. 109:267-274. 